\title{
KETAHANAN BETON fc' 22,5 MPa TERHADAP KONDISI AIR KOTA PALANGKA RAYA
}

\author{
Norseta Ajie Saputra*1, Noviyanthy Handayani² \\ ${ }^{1,2}$ Dosen / Program Studi Teknik Sipil / Fakultas Teknik / \\ Universitas Muhammadiyah Palangkaraya \\ *Korespondensi : civil@umpalangkaraya.ac.id
}

\begin{abstract}
Palangka Raya is a city where almost a part of the area is peatland with peat water with an acidity level of around 4.0 - 5.0 which can make concrete become porous and cause damage. This study is to determine the effect of peat water, Kahayan river water, and PDAM water on the compressive strength of concrete. In this study, the immersion of concrete samples was carried out for 28 days and 60 days. The measurement results are known that the $\mathrm{pH}$ of peat water is 4.0 while the $\mathrm{pH}$ of Kahayan river water and PDAM water is 5.0.

From the results note that in the 28 days immersion, peat water concrete has increased in compressive strength while concrete in Kahayan river water and PDAM water has decreased in compressive strength. However, during the 60 days immersion the peat water concrete decreased in compressive strength to 20,638 MPa (17.31\%). Whereas the Kahayan river water and PDAM water in the 60 days immersion experienced an increase in compressive strength values of 31,687 MPa (26.96\%) and 27,696 MPa (10.98\%). From these results, it can be concluded that the Kahayan river water with $\mathrm{pH}=5.0$ does not make the concrete lose its strength and can survive in an acidic environment.
\end{abstract}

Keywords : an acidity level; concrete compressive strength; the immersion water

\section{PENDAHULUAN}

Kekuatan beton dipengaruhi dari komposisi pembentuknya, yaitu agregat, semen dan air. Selain itu, kondisi lingkungan dimana beton itu berada juga turut mempengaruhi kekuatan beton itu sendiri. Struktur beton yang langsung bersentuhan dengan air tawar, air payau/air laut, air gambut, air sungai, dan air tanah berpotensi menimbulkan kerusakan beton itu sendiri. Struktur beton harus mampu menghadapi kondisi dimana beton direncanakan tanpa mengalami kerusakan (deterioration) selama jangka waktu yang direncanakan [1].

Pandiangan [2], melakukan pengujian beton mutu tinggi dilingkungan asam. Mutu beton yang direncanakan adalah sebesar 50 MPa. Perendaman beton dilakukan pada umur beton $0,1,7,14,21,28,42,56,72,84$, dan 91 hari. Beton yang direndam pada air biasa akan mengalami peningkatan kekuatan beton. Beton yang direndam pada air gambut cenderung menurunkan kekuatan beton. Beton pada air rendaman asam sulfat dengan $\mathrm{pH}=5,0$ cenderung tidak menurunkan kekuatan beton.
Handayani [3] melakukan penelitian dengan cara membuat sampel beton K-250 sebanyak 27 buah yang tiap 3 sampel dilakukan perendaman pada air gambut, air sungai Kahayan dan air ledeng selama satu bulan, dua bulan dan tiga bulan.

Hasil penelitian menunjukkan bahwa beton yang direndam air gambut mengalami penurunan paling besar bila dibandingkan dengan beton yang direndam air sungai Kahayan dan air ledeng, yaitu sebesar $8,798 \%$ dari kuat tekan beton rencana sebesar $250 \mathrm{~kg} / \mathrm{cm}^{2}$. Sedangkan beton dengan rendaman air sungai mengalami penurunan sebesar 5,882\% dan beton dengan rendaman air ledeng 2,966\% dari kuat tekan beton rencana sebesar $250 \mathrm{~kg} / \mathrm{cm}^{2}$.

Bangunan beton yang berada di Kota Palangka Raya hampir sebagian bersentuhan dengan air gambut dan air sungai Kahayan, yang memungkinkan adanya perubahan kekuatan beton.

Adanya karakteristik air gambut yang memiliki sifat asam dan dapat merusak kekuatan beton inilah yang menjadi dasar penelitian ini. 
Adapun tujuan penelitian adalah untuk mengetahui dan menganalisis perubahan kuat tekan beton yang terjadi bila beton direndam pada air gambut dan air sungai Kahayan selama 28 hari dan 60 hari.

\section{TINJAUAN PUSTAKA}

\subsection{Kualitas Air}

Kota Palangka Raya terbelah oleh sungai besar yaitu Sungai Kahayan dan masih banyaknya wilayah hutan kota yang karakteristik tanahnya berupa tanah gambut. Daerah Kalampangan salah satu daerah yang memiliki daerah gambut yang sangat luas dan memiliki pH sebesar 5,14 [4].

Air gambut adalah air permukaan yang banyak terdapat di daerah berawa maupun dataran rendah terutama di Sumatera dan Kalimantan, yang mempunyai karakteristik sebagai berikut yaitu intensitas warna tinggi (warna merah kecoklatan), $\mathrm{pH}$ rendah, kandungan zat organik tinggi, kekeruhan dan kandungan partikel tersuspensi rendah, dan kandungan kation rendah.

Air gambut bersifat asam dengan $\mathrm{pH} 3,7-$ 5,3 [5]. Tanah dengan $\mathrm{pH}$ yang relatif tinggi $(\mathrm{pH}$ sekitar 5) umumnya dijumpai pada daerahdaerah yang mengalami pembakaran.

Air gambut yang bersifat asam akan menimbulkan masalah bagi konstruksi beton di daerah yang berupa lahan gambut, karena menurut Neville [6] tidak ada semen portland yang tahan terhadap serangan asam. Serangan asam membuat pasta semen mengalami korosi, sehingga dapat menimbulkan ekspansi, retak dan kehancuran pada beton.

Air sungai Kahayan yang berada di kota Palangka Raya selain sebagai sumber air utama keperluan sehari-hari penduduk yang hidup berada di pinggiran sungai juga digunakan sebagai sumber pemasok air PDAM yang mengaliri seluruh kota. Berdasarkan penelitian yang dilakukan Novrianti, et al [7] yang melakukan penelitian kualitas air sungai Kahayan yang dilakukan pada 6 titik yang berbeda menunjukkan bahwa pH air 5,36-6,61 yang berarti air sungai Kahayan memiliki derajat keasaman yang tinggi. Hal ini menguatkan hasil uji petik yang dilakukan BBTKLPP Banjarbaru pada tanggal 5-8 Maret 2013 yang mengambil 8 sampel air PDAM kota Palangka Raya menunjukkan $\mathrm{pH}$ air berkisar antara 5,81-6,12.
Derajat keasaman pada air PDAM ini dipengaruhi oleh sumber air baku PDAM yang berasal dari Sungai Kahayan itu sendiri. Hal ini disebabkan oleh banyaknya daerah rawa dan tanah gambut yang mengelilinginya. Air inilah yang kemudian mengalir ke sungai yang menyebabkan $\mathrm{pH}$ air sungai Kahayan dan PDAM tidak jauh beda.

Air dengan $\mathrm{pH}$ lebih dari 9,0 akan berasa basa dan dapat menyebabkan pergerakan pada wadah air dan mengurangi busa sabun. Air PDAM hendaknya harus bisa mempertahankan produksi airnya pada batas aman dan normal (pH 6,5 - 8,5) sehingga tidak merugikan kesehatan pemakainya [8].

\subsection{Klasifikasi Beton}

Berdasarkan klasifikasi oleh Departemen Pekerjaan Umum, mutu beton berdasarkan kuat tekannya dibagi menjadi tiga jenis, yaitu beton mutu rendah, beton mutu sedang dan beton mutu tinggi [9]. Pembagian klasifikasi berdasarkan kuat tekan beton tersebut dinyatakan dalam Tabel 1 berikut:

Tabel 1. Mutu Beton dan Penggunaan*))

\begin{tabular}{|c|c|c|c|}
\hline $\begin{array}{l}\text { Jenis } \\
\text { beton }\end{array}$ & $\begin{array}{c}\text { Kuat } \\
\text { Tekan/f'c } \\
\text { (MPa) }\end{array}$ & $\begin{array}{c}\sigma b k^{\prime} \\
\left(\mathrm{kg} / \mathrm{cm}^{2}\right)\end{array}$ & Uraian \\
\hline $\begin{array}{l}\text { Mutu } \\
\text { Tinggi }\end{array}$ & $35-65$ & $\begin{array}{c}\text { K400 - } \\
\text { K800 }\end{array}$ & $\begin{array}{l}\text { Umumnya } \\
\text { untuk beton } \\
\text { prategang } \\
\text { seperti tiang } \\
\text { pancang beton } \\
\text { prategang, } \\
\text { gelagar beton } \\
\text { prategang, plat } \\
\text { beton prategang } \\
\text { dan seienisnya. }\end{array}$ \\
\hline $\begin{array}{c}\text { Mutu } \\
\text { Sedang }\end{array}$ & $20-<35$ & $\begin{array}{c}\mathrm{K} 250-< \\
\mathrm{K} 400\end{array}$ & $\begin{array}{l}\text { Umumnya } \\
\text { digunakan } \\
\text { untuk beton } \\
\text { bertulang } \\
\text { seperti pelat } \\
\text { lantai jembatan, } \\
\text { gelagar beton } \\
\text { bertulang, } \\
\text { diafragma, kerb } \\
\text { beton pracetak, } \\
\text { gorong-gorong } \\
\text { beton bertulang, } \\
\text { bangunan }\end{array}$ \\
\hline
\end{tabular}




\begin{tabular}{|c|c|c|c|}
\hline $\begin{array}{l}\text { Jenis } \\
\text { beton }\end{array}$ & $\begin{array}{c}\text { Kuat } \\
\text { Tekan/f'c } \\
(\mathrm{MPa})\end{array}$ & $\begin{array}{c}\sigma b k^{\prime} \\
\left(\mathrm{kg} / \mathrm{cm}^{2}\right)\end{array}$ & Uraian \\
\hline \multirow[t]{2}{*}{$\begin{array}{l}\text { Mutu } \\
\text { Rendah }\end{array}$} & $15-<20$ & $\begin{array}{c}\mathrm{K} 175-< \\
\mathrm{K} 250\end{array}$ & $\begin{array}{l}\text { Umumnya } \\
\text { digunakan } \\
\text { untuk struktur } \\
\text { beton tanpa } \\
\text { tulangan seperti } \\
\text { beton siklop, } \\
\text { trotoar dan } \\
\text { pasangan batu } \\
\text { kosong yang } \\
\text { diisi adukan, } \\
\text { pasangan batu. }\end{array}$ \\
\hline & $10-<15$ & $\begin{array}{c}\mathrm{K} 125-< \\
\mathrm{K} 175\end{array}$ & $\begin{array}{l}\text { Digunakan } \\
\text { sebagai lantai } \\
\text { kerja, } \\
\text { penimbunan } \\
\text { kembali dengan } \\
\text { beton. }\end{array}$ \\
\hline
\end{tabular}

)) Puslitbang Prasarana Transportasi, Divisi 7 - 2005

Mutu beton ditentukan oleh beberapa faktor antara lain:

a. Faktor Air Semen (f.a.s).

b. Perbandingan bahan-bahan campuran.

c. Mutu bahan-bahan campuran.

d. Susunan butiran agregat.

e. Ukuran maksimum agregat.

f. Bentuk butiran agregat.

g. Kondisi pada saat pengerjaan campuran.

h. Kondisi pada saat pengerasan.

\subsection{Mix Design Beton}

Desain campuran (mix design) beton menggunakan metode SNI 03-2834-1993 [1] dengan kuat tekan rencana f'c 22,5 MPa pada umur perawatan 28 dan 60 hari. Benda uji beton berbentuk silinder dengan dimensi $15 \mathrm{~cm} \times 30$ $\mathrm{cm}$ untuk pengujian kuat tekan.

\subsection{Kuat Tekan Beton}

Pengujian kuat tekan beton, benda uji berupa silinder beton dengan diameter dimensi $15 \mathrm{~cm} \times 30 \mathrm{~cm}$ ditekan dengan beban P sampai runtuh. Karena ada beban tekan P, maka terjadi tegangan tekan pada beton $\left(\sigma_{\mathrm{c}}\right)$ sebesar beban (P) dibagi dengan luas penampang beton (A), sehingga dirumuskan sebagai berikut :

$\sigma_{c}=\frac{P}{A}$ dengan :

$\sigma_{\mathrm{c}}=$ tegangan tekan beton, $\mathrm{MPa}$

$\mathrm{P}=$ beban tekan, Newton

$\mathrm{A}=$ luas penampang beton, $\mathrm{mm}^{2}$

\section{METODE PENELITIAN}

\subsection{Bagan Alur Penelitian}

Pelaksanaa penelitian dilakukan dengan cara bertahap sehingga dari hasil percobaan dapat memperoleh hasil penelitian yang sangat teliti, dan proses alur pelaksanaan penelitian seperti pada Gambar 1.

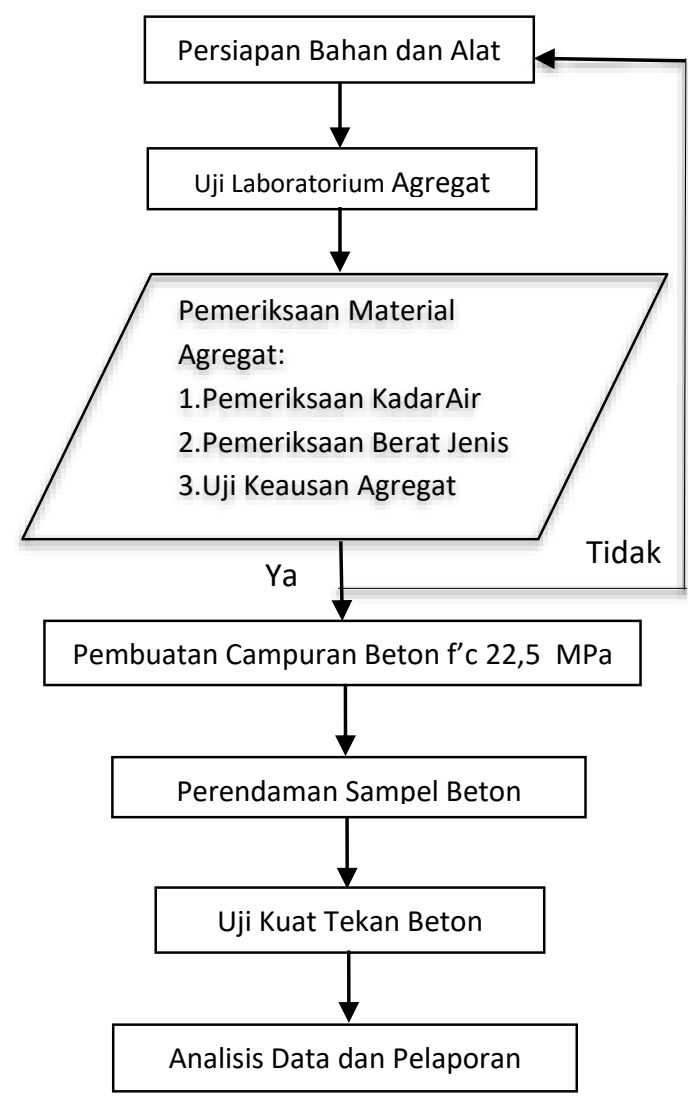

Gambar 1. Diagram Alir Rencana Penelitian

\subsection{Pemeriksaan Karakteristik Material Agregat}

Agregat kasar berupa batu pecah yang digunakan berasal dari Ex. Merak, sedangkan agregat halus berupa pasir alam berasal dari Tangkiling Jalan Tjilik Riwut Km 29 Palangka Raya.

Jenis-jenis pemeriksaan material meliputi:

1. Pemeriksaan Kadar Air

2. Pemeriksaan Berat Jenis

3. Uji Ketahanan Aus 


\subsection{Pembuatan Sampel Beton}

Beton yang digunakan dalam pengujian adalah beton normal dengan kuat tekan rencana ( $f^{\prime} \mathrm{c}=22,5 \mathrm{MPa}$ ) dan benda uji silinder dengan dimensi $15 \mathrm{~cm} \times 30 \mathrm{~cm}$. Adapun rincian jumlah benda uji beton adalah sebagai berikut :

Tabel 2. Jumlah Benda Uji Beton

\begin{tabular}{c|l|c|c}
\hline No. & $\begin{array}{c}\text { Air } \\
\text { Rendaman }\end{array}$ & $\begin{array}{c}\text { Waktu } \\
\text { Perendaman }\end{array}$ & $\begin{array}{c}\text { Jumlah } \\
\text { benda uji }\end{array}$ \\
\hline 1 & Air gambut & 28 hari & 3 buah \\
& & 60 hari & 3 buah \\
\hline 2 & Air sungai & 28 hari & 3 buah \\
& Kahayan & 60 hari & 3 buah \\
\hline 3 & Air PDAM & 28 hari & 3 buah \\
& & 60 hari & 3 buah \\
\hline \multicolumn{2}{l}{ Total Benda Uji } & \multicolumn{3}{c}{18 buah } \\
\hline
\end{tabular}

\subsection{Perendaman Beton}

Perendaman beton akan dilakukan ditempat air perendaman itu berasal (sesuai kondisi aslinya).

Air gambut yang digunakan berada di jalan G. Obos Ujung kota Palangka Raya, air sungai Kahayan dan air PDAM yang mengalir di laboratorium Struktur UM Palangkaraya.

\section{HASIL DAN PEMBAHASAN}

\subsection{Hasil Pengujian Karakteristik Material \\ Agregat}

Material penyusun beton yang digunakan pada penelitian ini dapat dilihat pada Tabel 3 berikut.

Tabel 3. Material Penyusun Beton fc' 22,5

\begin{tabular}{c|c|c}
\multicolumn{3}{|c}{ MPa } \\
\hline No. & Material & Sumber \\
\hline 1 & Semen & PC merk Gresik tipe 1 \\
\hline 2 & Agregat & Pasir Tangkiling \\
& Halus & \\
\hline 3 & $\begin{array}{c}\text { Agregat } \\
\text { Kasar }\end{array}$ & Batu Pecah ex. Merak \\
\hline 4 & Air & $\begin{array}{c}\text { Air di Lab.struktur } \\
\text { Fak.Teknik }\end{array}$ \\
\hline
\end{tabular}

Jenis-jenis pemeriksaan material yang dilaksanakan meliputi:

1. Pemeriksaan Kadar Air Agregat

2. Pemeriksaan Berat Jenis

3. Uji Ketahanan Aus

Adapun hasil pengujian karakteristik material dapat dilihat pada Tabel 4.
Tabel 4. Hasil Pengujian Karakteristik Material

\begin{tabular}{l|c|c|c}
\hline Jenis Pemeriksaan & $\begin{array}{c}\text { Aggregat } \\
\text { Kasar }\end{array}$ & $\begin{array}{c}\text { Agregat } \\
\text { Halus }\end{array}$ & Standar \\
\hline Kadar air (\%) & 0,86 & 3,27 & \\
\hline
\end{tabular}

Berat Jenis (gr/ $\left.\mathrm{cm}^{3}\right)$

\begin{tabular}{|c|c|c|c|}
\hline $\begin{array}{l}\text { a. Specific gravity } \\
\text { (apparent) }\end{array}$ & 2,694 & 2,658 & $\begin{array}{c}2,58- \\
2,84\end{array}$ \\
\hline $\begin{array}{l}\text { b. Specific gravity } \\
\text { (bulk) }\end{array}$ & 2,607 & 2,616 & $\begin{array}{c}2,58- \\
2,85\end{array}$ \\
\hline $\begin{array}{l}\text { c. Specific gravity } \\
\text { (SSD) }\end{array}$ & 2,640 & 2,632 & $\begin{array}{c}2,58- \\
2,86\end{array}$ \\
\hline $\begin{array}{l}\text { d. Penyerapan air } \\
(\%)\end{array}$ & 1,235 & 0,604 & $\begin{array}{c}2,00- \\
7,00\end{array}$ \\
\hline Keausan (\%) & 20,78 & - & $<40$ \\
\hline
\end{tabular}

Hasil Penelitian (2019)

\subsection{Hasil Pengujian Kandungan Air Kota Palangka Raya}

\subsubsection{Air Gambut}

Air gambut yang digunakan dalam penelitian ini berasal dari daerah kawasan Jalan G.Obos Lingkar Luar Palangka Raya. Indikator yang digunakan adalah derajat keasaman $(\mathrm{pH})$. Derajat keasaman $(\mathrm{pH})$ air gambut dilapangan yaitu 4,0 .

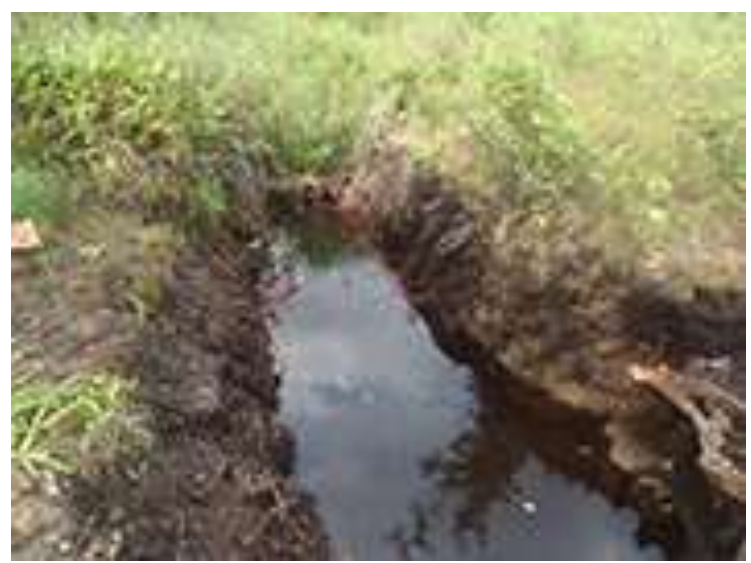

Gambar 2. Lokasi Perendaman Air Gambut

\subsubsection{Air Sungai Kahayan}

Air sungai Kahayan yang merupakan tempat lokasi perendaman beton berada disekitar daerah jembatan Kahayan. Hasil pengukuran $\mathrm{pH}$ menunjukkan bahwa $\mathrm{pH}$ air sungai Kahayan sebesar 5,0. Hal ini juga sama 
dengan hasil penelitian Novrianti [7] yang memperoleh hasil $\mathrm{pH}$ sungai Kahayan sekitar $5,36-6,61$.

\subsubsection{Air PDAM}

Air PDAM adalah sumber air utama untuk keperluan dan kebutuhan sehari-hari masyarakat Kota Palangka Raya. Berdasarkan hasil pemeriksaan laboratorium BBTKLPP Banjarbaru menunjukkan $\mathrm{pH}$ air berkisar antara 5,81-6,12 [8]. Sedangkan derajat keasaman pada air PDAM berdasarkan pengukuran yaitu 5,0. Hal ini juga juga diperkuat pernyataan BBTKLPP yaitu sumber utama air PDAM kota Palangka Raya adalah air sungai Kahayan yang ternyata memiliki kandungan nilai $\mathrm{pH}$ yang sama yaitu 5,0.

\subsection{Pembuatan Sampel Beton}

Penelitian ini terdiri dari 18 sampel silinder beton yang terdiri dari 6 sampel beton untuk perendaman air gambut, 6 sampel air sungai Kahayan dan 6 sampel air PDAM. Perendaman sampel beton dilakukan selama 1 bulan (28 hari) dan 2 bulan (60 hari). Perencanaan campuran beton untuk penelitian ini dapat dilihat pada Tabel 5.

Tabel 5. Komposisi campuran beton

\begin{tabular}{c|c|c|c|c}
\multicolumn{6}{c}{$\mathrm{fc}^{\prime}$} & $22,5 \mathrm{MPa}$ \\
\hline $\begin{array}{c}\text { Banyakny } \\
\text { a Bahan }\end{array}$ & $\begin{array}{c}\text { Seme } \\
\mathrm{n} \\
(\mathrm{kg})\end{array}$ & $\begin{array}{c}\text { Air } \\
(\text { liter })\end{array}$ & $\begin{array}{c}\text { Ag. } \\
\text { Halus } \\
(\mathrm{kg})\end{array}$ & $\begin{array}{c}\text { Ag. } \\
\text { Kasar } \\
(\mathrm{kg})\end{array}$ \\
\hline $\mathrm{m}^{3}$ & $\begin{array}{c}394,2 \\
3\end{array}$ & $\begin{array}{c}224,2 \\
0\end{array}$ & $\begin{array}{c}563,6 \\
0\end{array}$ & $\begin{array}{c}1217,2 \\
1\end{array}$ \\
\hline $\begin{array}{c}\text { Per 3 } \\
\text { silinder }\end{array}$ & $\begin{array}{c}7,835 \\
3\end{array}$ & 4,07 & 2,91 & 6,48 \\
\hline 1 silinder & $\begin{array}{c}2,089 \\
4\end{array}$ & 1,09 & 10,91 & 24,28 \\
\hline
\end{tabular}

Hasil Penelitian (2019)

\subsection{Hasil Pengujian Kuat Tekan Beton}

Saat umur beton sudah mencapai 28 hari, dan 60 hari maka sampel-sampel beton tersebut akan diuji kekuatan betonnya dengan melakukan Tes Kuat Tekan dengan nilai kuat tekan semula yaitu 24,957 MPa.

Adapun hasil kuat tekan untuk masingmasing air rendaman dapat dilihat pada Tabel 6. Nilai kuat tekan beton air gambut diatas, apabila disajikan dalam bentuk grafik, dapat dilihat pada Gambar 3.
Tabel 6. Hasil Tes Kuat Tekan Beton dengan rendaman air Gambut

\begin{tabular}{c|c|c|c|c}
\hline No. & $\begin{array}{c}\text { Umur } \\
\text { beton } \\
\text { (hari) }\end{array}$ & $\begin{array}{c}\text { Berat } \\
\text { Beton } \\
\text { (gram) }\end{array}$ & $\begin{array}{c}\text { Beban } \\
\text { Maks. } \\
(\mathrm{KN})\end{array}$ & $\begin{array}{c}\text { Kuat } \\
\text { Tekan } \\
(\mathrm{MPa})\end{array}$ \\
\hline 1 & 28 & 12515 & 420,80 & 23,812 \\
\hline 2 & 28 & 12438 & 435,20 & 24,627 \\
\hline 3 & 28 & 12528 & 476,30 & 26,953 \\
\hline 4 & 60 & 12137 & 267,40 & 15,132 \\
\hline 5 & 60 & 12502 & 310,50 & 17,571 \\
\hline 6 & 60 & 12377 & 418,90 & 23,705 \\
\hline
\end{tabular}

Sumber : Hasil Penelitian (2019)

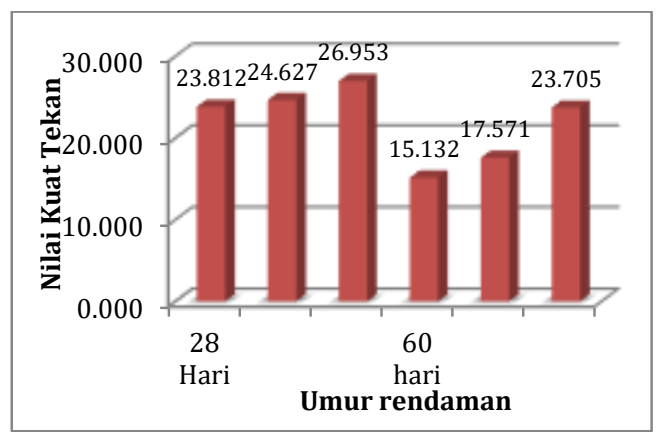

Gambar 3. Grafik kuat tekan beton air gambut (Hasil Penelitian, 2019)

Dari Tabel 6 dan Gambar 3 terlihat bahwa kuat tekan beton mengalami penurunan drastis pada saat perendaman 60 hari bila dibandingkan pada perendaman 28 hari.

Sedangkan untuk rendaman air sungai Kahayan, dapat dilihat pada Tabel 7 dan Gambar 4.

Tabel 7. Hasil Tes Kuat Tekan Beton dengan rendaman air Sungai Kahayan

\begin{tabular}{c|c|c|c|c}
\hline No. & $\begin{array}{c}\text { Umur } \\
\text { beton } \\
\text { (hari) }\end{array}$ & $\begin{array}{c}\text { Berat } \\
\text { Beton } \\
\text { (gram) }\end{array}$ & $\begin{array}{c}\text { Beban } \\
\text { Maks. } \\
(\mathrm{KN})\end{array}$ & $\begin{array}{c}\text { Kuat } \\
\text { Tekan } \\
(\mathrm{MPa})\end{array}$ \\
\hline 1 & 28 & 12373 & 391,40 & 22,149 \\
\hline 2 & 28 & 12382 & 401,50 & 22,720 \\
\hline 3 & 28 & 12532 & 437,90 & 24,780 \\
\hline
\end{tabular}




\begin{tabular}{c|c|c|c|c}
\hline No. & $\begin{array}{c}\text { Umur } \\
\text { beton } \\
\text { (hari) }\end{array}$ & $\begin{array}{c}\text { Berat } \\
\text { Beton } \\
\text { (gram) }\end{array}$ & $\begin{array}{c}\text { Beban } \\
\text { Maks. } \\
(\mathrm{KN})\end{array}$ & $\begin{array}{c}\text { Kuat } \\
\text { Tekan } \\
(\mathrm{MPa})\end{array}$ \\
\hline 4 & 60 & 12337 & 433,60 & 24,537 \\
\hline 5 & 60 & 12411 & 488,60 & 27,649 \\
\hline 6 & 60 & 12512 & 631,30 & 35,724 \\
\hline
\end{tabular}

Sumber : Hasil Penelitian (2019)

Apabila nilai kuat tekan beton air sungai Kahayan tabel diatas, jika disajikan dalam bentuk grafik, dapat dilihat pada Gambar 4.

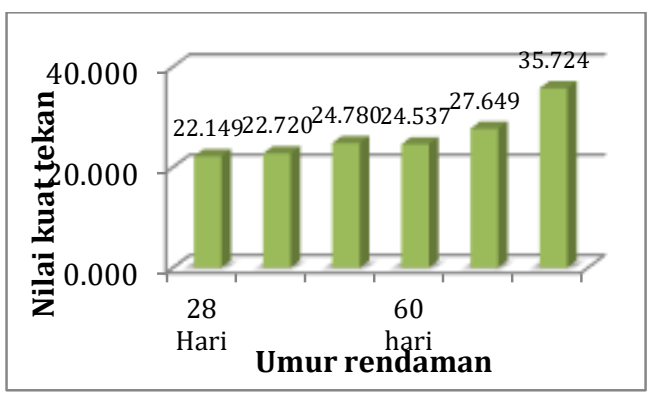

Gambar 4. Grafik kuat tekan beton air sungai Kahayan (Hasil Penelitian, 2019)

Untuk sampel beton yang direndam di sungai Kahayan, menunjukkan nilai kuat tekan yang hampir sama di 28 hari dan 60 hari perendamannya.

Sedangkan untuk hasil pengujian kuat tekan beton air PDAM dapat dilihat pada Tabel 8 dan Gambar 5.

Tabel 8. Hasil Tes Kuat Tekan Beton dengan rendaman air PDAM

\begin{tabular}{c|c|c|c|c}
\hline No. & $\begin{array}{c}\text { Umur } \\
\text { beton } \\
\text { (hari) }\end{array}$ & $\begin{array}{c}\text { Berat } \\
\text { Beton } \\
\text { gram) }\end{array}$ & $\begin{array}{c}\text { Beban } \\
\text { Maks. } \\
(\mathrm{KN})\end{array}$ & $\begin{array}{c}\text { Kuat } \\
\text { Tekan } \\
(\mathrm{MPa})\end{array}$ \\
\hline 1 & 28 & 12420 & 428,10 & 24,225 \\
\hline 2 & 28 & 12464 & 437,00 & 24,729 \\
\hline 3 & 28 & 12495 & 469,90 & 26,591 \\
\hline 4 & 60 & 12499 & 419,00 & 23,710 \\
\hline 5 & 60 & 12416 & 427,40 & 24,186 \\
\hline 6 & 60 & 12340 & 621,90 & 35,192 \\
\hline \multicolumn{5}{|c|}{} \\
\hline \multicolumn{5}{|c|}{ Sumber Hasil Penelitian (2019) } \\
\hline
\end{tabular}

Sedangkan untuk nilai kuat tekan beton air PDAM kota Palangka Raya seperti yang diperlihatkan tabel diatas, jika disajikan dalam bentuk grafik, dapat dilihat pada Gambar 5.

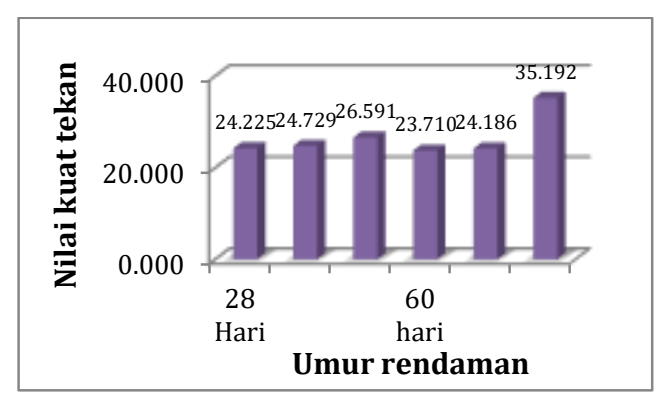

Gambar 5. Grafik kuat tekan beton air PDAM (Hasil Penelitian, 2019)

Pada Gambar 5, terlihat bahwa beton pada air PDAM, menunjukkan nilai kuat tekan yang hampir sama di tiap bulan perendamannya. Hal ini juga menunjukkan bahwa kuat tekan air rendaman sungai Kahayan dan PDAM hampir serupa, yang disebabkan oleh air PDAM bersumber pada air sungai Kahayan dan memiliki $\mathrm{pH}$ yang sama.

Sedangkan untuk hasil kuat tekan ratarata sampel beton tiap bulannya dapat dilihat pada Tabel 9 dengan nilai kuat tekan awal 24,957 MPa.

Tabel 9. Hasil Tes Kuat Tekan Rata-rata

\begin{tabular}{c|c|c|c|c}
\hline \multirow{2}{*}{ No. } & \multirow{2}{*}{$\begin{array}{c}\text { Umur } \\
\text { beton } \\
\text { (hari) }\end{array}$} & \multicolumn{3}{|c}{ Kuat Tekan Rata-rata (MPa) } \\
\cline { 3 - 5 } & Air Gambut & $\begin{array}{c}\text { Air Sungai } \\
\text { Kahayan }\end{array}$ & $\begin{array}{c}\text { Air } \\
\text { PDAM }\end{array}$ \\
\hline 1 & 28 & 25,790 & 23,750 & 24,477 \\
\hline 2 & 60 & 20,638 & 31,687 & 27,696 \\
\hline \multicolumn{5}{|l|}{ Sumber : Hasil Penelitian (2019) }
\end{tabular}

Sumber : Hasil Penelitian (2019)

Apabila nilai kuat tekan rata-rata tersebut disajikan dalam grafik, dapat dilihat pada Gambar 6. Terlihat dari Gambar 6, pada rendaman 28 hari, untuk beton dengan perendaman air gambut mengalami kenaikan kuat tekan bila dibandingkan dengan beton yang direndam air sungai Kahayan dan air PDAM. Sedangkan pada rendaman 60 hari terlihat bahwa beton air gambut mengalami penurunan yang cukup besar bila dibandingkan kuat tekan 
semula yaitu 24,957 MPa menjadi 20,638 $\mathrm{MPa}$ atau sebesar $17,31 \%$.

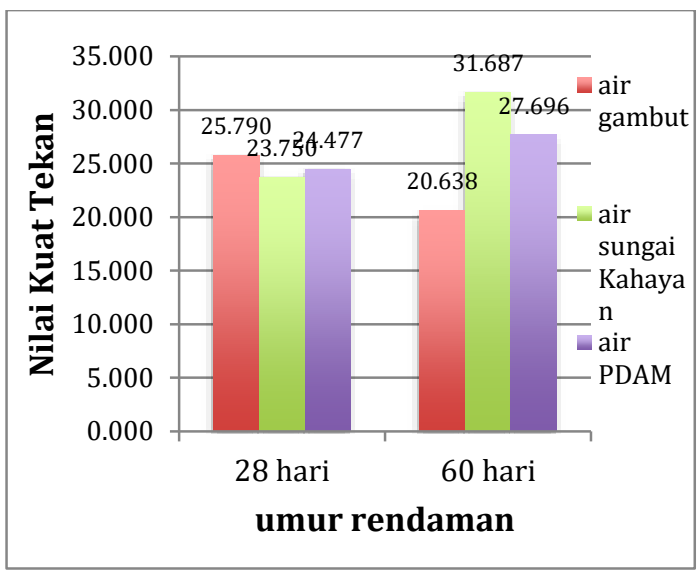

Gambar 6. Grafik kuat tekan rata-rata (Hasil Penelitian, 2019)

Sementara itu, beton yang direndam air sungai Kahayan untuk perendaman 28 hari mengalami penurunan kuat tekan menjadi 23,750 MPa akantetapi pada perendaman 60 hari mengalami kenaikan menjadi $31,687 \mathrm{MPa}$ atau sebesar 26,96\%.

Sedangkan untuk beton yang direndam air PDAM mengalami penurunan pada rendaman 28 hari yaitu menjadi $24,477 \mathrm{MPa}$. Akan tetapi pada perendaman 60 hari kuat tekan beton meningkat sebesar 27,696 $\mathrm{MPa}$ atau sebesar $10,98 \%$.

\subsection{Pembahasan}

Hasil pengujian kuat tekan beton pada rendaman air gambut 28 hari dan 60 hari menunjukkan sampel beton mengalami penurunan kuat tekan dari semula $24,957 \mathrm{MPa}$ menjadi 23,416 MPa atau sebesar 6,18\%. Hal ini menunjukkan hasil yang sama pada penelitian yang dilakukan [3] yang menunjukkan penurunan kuat tekan sampel beton sebesar $8,798 \%$.

Sedangkan penelitian yang dilakukan Pandiangan [2] menunjukkan bahwa beton yang direndam pada air gambut cenderung menurunkan kekuatan beton dan beton pada air rendaman asam sulfat dengan $\mathrm{pH}=5,0$ cenderung tidak menurunkan kekuatan beton. Hal ini juga terlihat pada beton rendaman air sungai Kahayan dan air PDAM yang memiliki $\mathrm{pH}=5,0$ memiliki nilai kuat tekan pada rendaman 60 hari tidak menurunkan nilai kuat tekan beton, akan tetapi meningkatkan nilai kuat tekan beton, dari yang semula 24,957 $\mathrm{MPa}$ menjadi 31,687 MPa dan 27,696 MPa.

\section{KESIMPULAN}

Hasil penelitian yang telah dilakukan dapat ditarik beberapa kesimpulan yaitu :

1. Derajat keasaman $(\mathrm{pH})$ sampel air rendaman yaitu air gambut sebesar 4,0, air sungai Kahayan 5,0 dan air PDAM 5,0.

2. Beton yang direndam di air gambut mengalami penurunan kuat tekan. Penurunan terbesar terjadi pada rendaman 60 hari yaitu sebesar $17,31 \%$ dari kuat tekan semula yaitu 24,957 MPa menjadi 20,638 MPa.

3. Beton yang direndam di air sungai Kahayan dan PDAM secara umum mengalami kenaikan, dimana kenaikan nilai kuat tekan terbesar terjadi pada 60 hari rendaman yaitu $31,687 \mathrm{MPa}$ atau sebesar 26,96\% dan 27,696 $\operatorname{MPa}(10,98 \%)$.

4. Dari ketiga air yang berada di Kota Palangka Raya, dapat dikatakan bahwa air sungai Kahayan dengan $\mathrm{pH}=5,0$ memiliki kualitas air rendaman beton yang terbaik, yang bisa meningkatkan nilai kuat tekan betonnya, sehingga apabila ada bangunan beton yang berada di lingkungan dengan $\mathrm{pH}=5,0$ maka bisa diasumsikan bangunan itu akan bertahan sesuai umur rencana pembangunannya.

\section{UCAPAN TERIMA KASIH}

Penelitian ini dapat dilaksanakan karena bantuan dari Program Penelitian Kompetitif Dosen Internal (PKDI) Lembaga Penelitian dan Pengabdian Kepada Masyarakat Universitas Muhammadiyah Palangkaraya.

\section{DAFTAR PUSTAKA}

[1] Kurniawandy, Alex, Lita Darmayanti, and Ucok H. Pulungan. "Pengaruh Intrusi Air Laut, Air Gambut, Air Kelapa, Dan Air Biasa Terhadap Kuat Tekan Beton Normal." Jurnal Sains dan Teknologi 11.2. September 2012

[2] Pandiangan, Jaya Alexander. Olivia, Monita dan Darmayanti, Lita (2014). Ketahanan Beton Mutu Tinggi Di Lingkungan Asam. Laporan Penelitian Mahasiswa dan Dosen Universitas Riau. Jurnal Online Mahasiswa Fakultas Teknik Universitas Riau

[3] Handayani, Noviyanthy. (2018) Ketahanan Beton Normal Terhadap Air Gambut di Kota Palangka Raya. Jurnal Media Ilmiah Teknik Sipil Vol. 7 No. 1 Desember 2018

[4] Itta, Daniel., Asysyifa dan Satriadi, Trisnu. Karakteristik Lahan Gambut dan Pola 
Argoforestri di kelurahan Kalampangan Kota Palangka Raya Kalimantan Tengah https://www.fordamof.org//files/OB5 KARAKTERISTIK LAH AN_GAMBUT_daniel_.pdf_diunduh 10 September 2019

[5] Eri, Iva Rustanti dan Hadi, Wahyono. (2008). Kajian Pengolahan Air Gambut Menjadi Air Bersih dengan Kombinasi Proses Upflow Anaerobik Filter dan Slow Sand Filter, Tesis Program Pascasarjana Teknik Sipil. Institut Teknologi Sepuluh November. Surabaya

[6] Neville, Adam M. (2011). Properties of Concrete -5th Edition. Pearson Education Limited. London.
[7] Novrianti., Lesmana, Rudy Yoga., dan Apriyani, Nani. Dampak pencemaran limbah domestic pada kualitas air sungai

(studi Kasus : Sub DAS Kahayan Daerah Mendawai Jln Tjilik Riwut Km 1,5 Kota Palangka Raya, Kalimantan Tengah) Laporan Penelitian, Universitas Muhammadiyah Palangkaraya, Palangka Raya, 2018.

[8] BBTKLPP BANJARBARU

Uji petik kualitas air di kota Palangka Raya http://bbtklbjb.net/2016/04/17/uji-petik-

kualitas-air-di-kota-palangka-raya/ diunduh 10 September 2019

[9] Departemen Pekerjaan Umum, Puslitbang Prasarana Transportasi, Spesifikasi Umum 2010 (Revisi 3) Divisi 7 Struktur Seksi 7.1 Beton, 